The Journal of Society and Media, April 2021, Vol. 5(1) 151-172

https://journal.unesa.ac.id/index.php/jsm/index

E-ISSN 2580-1341 and P-ISSN 2721-0383

Accredited KEMENRISTEK/ BRIN No.148/M/KPT/2020

DOI: 10.26740/jsm.v5n1.p151-172

\title{
Black November: Interrogating The Niger Delta Question
}

\author{
Chukwuma Anyanwu ${ }^{\text {* }}$ \\ ${ }^{1}$ Faculty of Arts, Delta State University, Abraka \\ Email: anyanwubc@ delsu.edu.ng
}

\begin{abstract}
The paper interrogates the thematic preoccupations of Jeta Amata's Black November on the vexed issues of the Niger Delta in Nigeria. The issues bordering on the quest for emancipation from injustice, environmental degradation, deprivation, inhuman treatment, negligence, are at the nexus of the agitations and militancy in the region. It draws inferences from what the movie overlooked and what it portrayed such as the failure of dialogue births violence. The objective is to highlight the problems in the Niger Delta and give credence to the thematic concerns raised by the director. Based on Relative Deprivation Theory (RDT), which sees violence as a product of frustration borne out of depriving people of their rights, denial of justice; a sense of oppression sets in that then leads to reactions that may be violent. The method adopted is descriptive analysis. Findings reveal that the Niger Delta region is much misunderstood, abused and betrayed by its own people, the media, Nigerian government, oil multinationals and the world at large. It concludes that the misunderstanding is largely a product of media misinformation and that of ignorance on the part of stakeholders and that the filmmaker succeeded in getting his message across.
\end{abstract}

Keywords: film, niger delta, nigeria, oppression, ntural resources

Paper type: Research paper

*Corresponding author: anyanwubc@delsu.edu.ng

Submited: 2020-05-19; Accepted: 2021-04-27; Published: 2021-04-29

Cite this document: Anyanwu, Chukwuma. (2021). Black November: Interrogating The Niger Delta Question. The Journal of Society and Media, 4(2), 151-172. DOI: 10.26740/jsm.v4n2.p151-172. 


\section{INTRODUCTION}

The Niger Delta is the heart of Nigeria's oil-dependent economy. For over 50 years, wealth from the region has sustained the nation's economy and stabilized the political system. The systemic plunder of the region's resources has made it possible for resource-famished but politically dominant sections of Nigeria to have more roads, bridges, modern communication, educational institutions, industries, real estates and generations of billionaires than the Niger Delta states (Darah 2014). Top on the array of such conflicts are the prolonged Niger Deltamilitancy in the oil-rich Niger Delta region, the Boko Haram insurgencyin the North Eastern region, and the myriad of ethnic cum religious conflicts, prominently, the herders/farmers conflicts that have spread throughthe North Central/North Eastern regions, and increased in intensity overthere past few years (Lucas, Vakkai, and Targema 2020). Although Nigeria has since attained independence, the minds of the people appear to be wilfully subjugated to the control of the hitherto colonial power (Licata et al. 2017). Oviasuyi and Uwadea argue that prior to when oil was discovered in the Niger Delta area, agriculture was the mainstay of the people and the major source of revenue for both state and federal government (Jim and Uwadiae 2010). The film demonstrates this issue as one of the major causes of conflict in the region. Prior to the discovery of crude oil in the region, farming and fishing were the major occupations of inhabitants (Apuke 2017).

The film industry in every culture plays several roles in the life of the culture that owns it. Some of these roles are innate and given; some are products of conscious efforts of the filmmaker while some, through their themes/subject matters, are happenstances, which the filmmaker never thought of while creating but which nevertheless, become part of his or her message. Patrick Ebewo argues that the film industry in Nigeria, now popularly referred to as Nollywood, which received impetus in 1993 with the release of the blockbuster Living in Bondage as produced by Kenneth Nnebue, has quickly and continuously gathered momentum over the last two decades emerging today as a force to reckon with globally (Ebewo 2007). Such is the case with Jeta Amata, a filmmaker concerned with the violence, destruction, rape, man's inhumanity to man, environmental degradation, youth restiveness and emancipation, among other disconcerting and worrisome issues which have become synonymous with the Niger Delta region of Nigeria. 
Idebor claims that Amata uses Black November as a means to address the injustice in the Niger Delta because "the voices of those at the subaltern level have become suppressed and denied even on issues and affairs that directly affect them" (Idebe 2019).

Film's importance in human society has been underlined by critics. However, the potential of the film has not been fully utilized for the advancement of the nation and human development. Many countries in the world with the United States (US) and India as the pioneers have used film media to provide a better life for their people. The film media continues to expand its spectrum and break down boundaries in new fields such as conflict management, social development, psycho-therapy, etc (Ebekue 2019).

But for its oil wells and the hardship, deprivation, death, and numerous tales of woe associated with the oil exploitation and exploration in this economic force and power house of the Nigerian nation, called the Niger Delta, many people would not have heard of it. Indeed, the Niger Delta region on account of the damage it has suffered in unquantifiable terms and measures in human, material, environmental, economic, social, political, spiritual, among other forms of atrocious experiences it has had to endure as a consequence of its natural resources, has become a-stop-action name in world affairs. The reason is quite simple: an enemy commands more attention than a friend. And the Niger Delta region of Nigeria has become through no fault of hers, or perhaps, because of her nature, the number one enemy of the world, epitomising in herself the quintessential example of the fate of the goose that lays the golden egg. In her case, however, the egg has become her albatross. Bazunu and Ekong noted that "crude oil is a natural resource like other resources. Its exploitation in the Niger Delta region of Nigeria has come with various environmental challenges that are common with such natural extractions" (Bazunu 2017). Oil exploitation, then, is the major problem that gave birth to virtually all the problems found in the region. Despite the Niger Delta region, providing Nigeria's total proven reserves of oil standing close to 25 billion barrels, which is an estimated 1.8 percent of the proven global reserves (Chiluwa 2011).

The Niger Delta question has thus revolved around the desire of the Niger Delta states to free themselves and their people from the evil and oppressive 
clutches of bad governance in connivance with equally obnoxious corporate policies of the multinational oil companies that dot the region in a bid to live better lives and get the dividends of the natural resources, notably, crude oil, that nature blessed them with. The region, like Nigeria, can be said to be at once "a geographical location and a political contraption" (Chinweizu 2013; Darah 2014; Falola 2013). The political arm has made it a sort of unwritten law to call any place in the country where oil is discovered in commercial or non-commercial quantity, Niger Delta.

The political agitations and the actions of militia groups in the creeks of the Niger Delta made the Obasanjo government to establish the Niger Delta Development Commission (NDDC) in 2000. The Commission's mandate area comprises the nine oil producing states of Abia, Akwa Ibom, Bayelsa, Cross River, Delta, Edo, Imo, Ondo, and Rivers (Darah 2014).

Darah in The Niger Delta: Resource Control and the Quest for Justice comprehensively and exhaustively traces the history of agitations, their origin, causes and effects, to the colonial era and with the discovery of oil at Oloibiri in 1956 (Darah 2014). The aftermath of the discovery was more like the scramble for Africa by Europe, only this time, it was for the oil wells of the Niger Delta and the struggle was by the various Nigerian governments, multinational oil companies and their countries of origin. The discovery of oil in the Niger Delta more than any other human or natural resource exposed "the leadership deficit, massive corruption, national security challenges, over dependence on oil, plummeting of oil prices in the global market, falling value of the naira in the forex market, etc," (Oju and Anyanwu 2018). The various governments, multinational oil companies and some individuals have reached the top in all manners of inhuman treatment, including murder, environmental degradation, and also of affluence.

Degradation, environmental pollution, underdevelopment, neglect and abuse of human rights are recurrent decimals and qualifiers when it comes to describing the Niger Delta. As Amata makes us understand through the heroine, Ebiere Perema, who is portrayed as the man through whose life and death the film came into being, Ken-Saro Wiwa had brought to the notice of the administrators of the Nigerian state and the international community the hazard and the systematic elimination of the people of Ogoni and by extension the people of the Nigeria-Delta through environmental degradation that is primarily due to the 
activities of the oil companies in the region (Dede 2017). The foregoing makes us understand that environmental degradation can be manmade and takes several forms; is destructive to humans, animals, birds, air, and water and just about everything. This is what the Niger Delta has been contending with for several decades now and the end is not in sight.

The Niger Delta has engendered much academic discourse and has been the cause of numerous public lectures, symposia, workshops, conferences, textbooks and creative engagements. All of those can be summed up as the relationship between an inhuman, atavistic oppressor and a helpless, docile, victim, the oppressed. The bad part in this unhealthy alliance being that the victim is the main raison d'être of the oppressor's very existence! Ibagere asserts that the Niger Delta is an area in dire need of development in all spheres of life (Ibagere 2011; Idebe 2019). This is despite its economic potentials which have been exploited for several decades with attendant criminal neglect through a wicked conspiracy of government and the multinational companies operating in the area...." the Niger Delta represents a paradox (rich but underdeveloped and poverty stricken). It presents a unique challenge in terms of development." Added to the neglect of the region is the environmental pollution and degradation which in combination with other factors have reduced the area to a plundered territory in need of rehabilitation.

Another worrying dimension to the conflict in the Niger Delta region is the role of dubious community leaders. Often times, they are use as the whip with which oil companies chastise residents (Nwankwo 2015). decries this unfortunate trend when he notes, that:

Ethnic nationalism in the Niger Delta has become one of the major problems in the region, as many people under the disguise of fighting for the economic emancipation of the Niger-Delta people exploit the oil companies and federal government by demanding money that never gets to the hands of the downtrodden citizens

Ibagere further adds that "the progressive degradation of the area soon compelled the people of the region to start the agitation for the control of their resources" (Ibagere 2011). Corroborating this, Darah documents the atrocious occurrences of the 1990s, which shall be quoted at some length, to properly foreground the discourse. In his words: 
It is pertinent to recall the experience of the bloody decade of the $1990 \mathrm{~s}$ that formed the background to the reforms under review. The first major use of the instruments of violence to handle an oil-related protest was at Umuechem in Ikwerre district of Rivers State in 1990. The community protested to Shell over neglect and demanded amenities such as roads, water and electricity supply. The police were invited; the royal ruler of the area and dozens were killed, besides numerous houses and property destroyed by the "kill-and-go-police". The Ogoni calamity was in the mid 1990s and eminent Ogoni citizens lost their lives. The police and the military were involved in the bloody suppression of the Ogoni revolt. After the hanging of the nine Ogoni activists in 1995, a special security squad spread terror and killing throughout the district. The number of innocent people that perished has not been ascertained and the government has not found it necessary to investigate allegations and charges of violation of human rights and atrocities committed by the death squads. To assuage the outrage of the international community, the Nigerian government set up the Niger Delta Environmental Study (NDES) outfit in 1995 which documented some of the horrors of oil spills and other ecological disasters. The NDES was headed by Gamaniel Onosode whose solid moral credentials raised public expectations. But the government did not even provide adequate funds for NDES to complete its data collation. The publication of findings was abandoned after a few volumes. (Pp.32-33).

It was shortly after this in October 1998 that a pipeline fire explosion occurred in Idjerhe (Jesse) area near Sapele in Delta State, leaving in its wake thousands of charred bodies burnt to death in the fire. The then military Head of State, General Abdulsalami Abubakar "visited the site; he was callous enough to say that the victims deserved to die because they were involved in illegal bunkering of petroleum products" (Darah 2014). The paper contributes to scholarship by expanding the knowledge space of literature on Amata's film in terms of its thematic engagements as well as drawing attention to the atrocities that have been committed in the Niger Delta. Some others works such as (Ayakoroma 2017) discussed issues of leadership challenges in the Niger Delta; did a comparative study of the situation with other films; and Omoera (2019) closely looked at human rights issues in October 1st and Black November, with reference to the Niger Delta. The other research from Dede and Dienye discussed issues of the dangers and systematic extermination of the Ogoni people as well as the Nigerian-Delta population through environmental degradation mainly caused by the activities of the oil companies in the region (Dede 2017). Ibagere in his research explained how the Niger Delta is an area that really needs development in all areas of life (Ibagere 2011). 


\section{METHOD}

The film medium is not only universally known and accepted; experts say that it speaks a universal language. It has close affinity with the people and can be deployed to treat any subject. In Africa, film is used beyond entertainment to serve as a medium of education, a means to articulate and project values, to agitate for freedom, for self expression and to right the wrongs of misrepresentation (Omoera and Anyanwu 2020; Shehu 1995; Ukadike 1995). In Nigeria, film has served various purposes, interrogating the concerns and issues of relevance to both the people and the governments. The documentary genre necessarily serves as the voice of the government in power, documenting its achievements and upholding its policies. The feature/fiction on the other hand, has been the thematic pitch of independent filmmakers who use it to narrate and creatively document aspects of the Nigerian experience.

In as much as film has been used generously to tell the story of Nigeria and Africa, many of the film makers shy away from politics notwithstanding that politics cannot be effectively divorced from art (Anyanwu 2008; Omoera 2019). Unfortunately, Nigerian filmmakers/artists do not have very pleasant memories of dabbling into political subjects as witnessed in the fate of Hubert Ogunde, Yoruba Ronu and Francis Oladele, Things Fall Apart/Bullfrog in the Sun, which were banned at the time of their production. Political subjects in movies have been presented as allegories and fictitious stories set in distant places with the characters barely recognizable. This is what plays out in Tunde Kelani's Saworoide (1999). However, the story is somewhat changing with the almost leaderless democratic climate where the breakaway tendency is most prominent among the ethnic nationalities that make up Nigeria.

Filmmakers are beginning to find their voices and courage to dabble into hitherto supposedly muddy political 'waters' of Nigerian terrain. In the same way, film has engendered academic and literary works and conversations of significance. The Niger Delta is once again, seeing in the film, a medium to be deployed in relaying the grievance and chronicle the horrendous holocaust to which the region has been subjected for universal attention and possible remediation. The region has, therefore, woken up to the potential of the film medium and the most significant ones to date are Okerenkoko, Liquid Black Gold 
and Black November. Of these, the last would be used to substantiate the foregoing submissions in this discourse. However, something about this title needs to be addressed. It has been noted that there was a pipeline fire outbreak in October 1998 which claimed thousands of lives. In December of the same year, "the all-Ijaw youth congress was held in Kaima, Isaac Boro's birthplace in Bayelsa State. The congress issued a revolutionary declaration on resource control." The aftermath of this declaration was that the civilian government of President Olusegun Obasanjo, on trumped allegation of killers of some police personnel, "ordered an armed invasion of Odi town in Bayelsa State" where the purported killers were taking refuge" (Darah 2014). This was in November 1999, and with one ultimatum given to the then governor of the state, D.S.P. Alamieyeseigha, "soldiers invaded and burnt down Odi town and sacked all inhabitants"(Darah 2014).

The film was titled Black November not as a reflection of the foregoing incidents, but as a memorial and in recognition of the efforts and sacrifice of one of the greatest human rights activists and environmentalists of the region, the writer, Kenule Saro-Wiwa, who was killed by the military despot, Late General Sani Abacha, in the month of November and who was represented by the lead character, Ebiere (Ayakoroma 2017). Also, there is contradictory date of production as what is in the movie is 2015 against the 2012 written on the jacket cover. Not-with-standing Nigerian filmmakers' reluctance to engage political issues, the film medium has remained a powerful medium of communication, entertainment and information dissemination (Emasealu 2008; Shaka 2003; Wetkos and Embu 2019). The unhealthy state of affairs in the Niger Delta thus provided for the filmmaker an avenue to tell "the story of every Niger Deltan through the character of Ebiere" (Kolade 2016). Amata's film is therefore, a trail blazer, creating the atmosphere for the world to be aware of the problems which the Niger Delta region of Nigeria is confronted with.

The paper adopts the Relative Deprivation Theory (RDT), to support its postulations. The theory interrogates the interconnectedness between political violence, socio-economic factors and human/individual mobilisation against oppression arising from perceived sense of deprivation, whether real or imagined. According to (Iyang and Morison Ime 2018) claim that "relative deprivation explains that people who are deprived of things deemed valuable in society- 
money, justice, status, privilege, opportunities or wealth- join social movements with the hope of redressing their grievances." Drawing from several sources while trying to explain the theory which they trace back to Aristotle's classical theory of revolution, Iyang and Imo affirm that "RDT holds the assumption that people are motivated to join social movements or advocate for social change based on their evaluation of what they think they should have compared with what others have." This is the exactly the feeling prevalent among the Niger Delta peoples of Nigeria, especially when they compare themselves with those who live in Lagos when it was the capital of Nigeria and now Abuja, the current federal capital territory. These centres are the main beneficiaries of the natural resources which emanate from the Niger Delta region.

Arising from this sense of deprivation, injustice, denial, oppression, etc., the Niger Delta people have to form themselves into several resistant and protest groups in the hope to right the wrongs they believe they have suffered and are still suffering. Such groups react with all manners of violence some of which appear to be unprovoked to the undiscerning mind, thus justifying the definition of violence as: a term that refers to an enormously complex, multi-determined range of phenomena. Some of the data concerning violence can only be explained in biological terms, some in psychological ones, and some in social, cultural, historical, and socio-economic terms. No theory of violence could be considered adequate except to the extent that it is capable of integrating all three levels of abstraction (Lawson and Bryn 2012). The situation in the Niger Delta region of Nigeria with regards to the feeling of deprivation is a veritable source of frustration which in turn gives rise to agitations of sorts. This theory is therefore quite appropriate as it lends credence to the central theme of the movie, Black November.

\section{RESULT AND DISCUSSION}

Black November: Synopsis of the story. The jacket cover of the movie, (Black November 2012), has the following synopsis in French: 
Nigeria. Un communaute fragile et ravagee fait la guerre a un gouverne corrompu pour sauver d'une destruction provoquee par des forages et des deversements de petrole excessifs. En quete de justice, un organisation rebelled kidnappe un magnat americain du petrole et exige que sa companie cesse le massacre. La tension monte trasformant ainsi un situation de prise d'otages en un veritable attentat a la bombe.

Roughly translated we get something that goes like this:

Nigeria. A very fragile and disorganized community/society, is at war with the corrupt government to save the land from destruction, perpetrated by spillage and diversion of excess petroleum fund. In search for justice, a rebel group kidnaps an American oil worker and insists that the company should stop the massacre. The tension builds up and aggravates into hostage taking thus making the place a time bomb. (Kennedy 2018).

(Black November 2012) directed by Jeta Amata, and assisted by Mickey Rourke, opens with the following graphics, Nigeria: Population 167 million. World's 7th most populous nation. Over 521 recognized languages, Ex-British colony. English is the official language and spoken throughout $90 \%$ of the population live on less than $\$ 2$ a day. World's $5^{\text {th }}$ largest exporter of oil. Continuous oil spills make it the most environmentally devastated land in the world.

Black November is a story which revolves around the Niger Delta people of Nigeria and the Western Oil Company; with the latter representing the entire multinational oil companies which dot the region. It is the tale of plunder and grabbing, of the oppressor at the various levels and the oppressed; a story of failed corporate social responsibility with the connivance of an inhuman and insensitive government on the one hand and the ignorant masses and a few corrupt elites, on the other. Set in the Niger Delta and Los Angeles, California in the United States of America, being the headquarters of the Western Oil Company, Ebiere Perema (Mbong Amata), a young graduate who ironically gets university education courtesy of Western Oil Company's corporate social responsibility through which it gives scholarship to deserving children from its host community, leads a protest. The relationship between Western Oil Company and its host community in the Niger Delta region cannot be said to cordial prior to Ebiere's birth and growing up some two decades earlier.

The events in the story peak and the pace of narration quickens with her birth. There have been oil spillages with their paraphernalia of casualties, 
compensations and reaping off of the victims by both the local elites, Western Oil Company staff and corrupt government officials before her birth with no one to speak out on behalf of the community. The very day Ebiere returns home from her studies abroad there is oil spillage and her entire family goes to scoop oil to to eke out a living. As she alights from the bike conveying her amidst shouts of "Mama, mama," she is informed that her mother, Barbara Soky, has gone with the others to scoop oil because "there has been another oil spill." She pays off the bike man; hurriedly puts her luggage inside the house and walks off in the direction of the spill to see her mother. She is thus in time to see the fire explosion and barely escapes by the skin of her teeth.

The horror of the charred remains of members of her family, including her mother and scores of other relatives firms her resolve to see that justice is done. Ebiere's involvement in social activism and becoming an environmental crusader cannot, therefore, be said to be an option. She is left with no choice as many militants are. While still trying to grapple with her loss she organises a protest to march to the capital city of Abuja and the headquarters of the oil company which are all greeted with violent resistance some leading to incarceration and death of some of the protesters. The last straw, however, is the paying of compensation arising from the oil spillage and the fire disaster there from by the oil company. The Western Oil Company through its spokesman, Gideon White, played by (Fred Amata), negotiates the sum of five hundred thousand US dollars $(\$ 500,000.00)$ as compensation for the victims. The contention here becomes who to be paid the money between individual families and the community as a whole. The money is eventually paid and, of course, the representative elders 'cornered' it for themselves. The only dissenting voice against this injustice is poisoned and his death and subsequent discovery of fifty thousand US dollars $(\$ 50,000.00)$ exposed the deceit, betrayal and double standards of the elders to the youths who have formed themselves as the resistance group. The conflicts generally revolve around who gets what and at whose expense. At a point during the discussion for compensation, it appears as if the misunderstanding is going to derail into gender issues as the spokesman for the men challenges Ebiere's right to speak for her family, because, according to him, this is an all male affair. But Ebiere counters 
by saying that the men in her family have been killed in the fire and at any rate, the issue is not gender based.

The youths in their anger, at the betrayal by the elders, led by Ebiere and Peter (OC Ukeje) whose father is poisoned by the elders because he threatened to expose them go in search of the elders and all those involved in the sabotage. Having rounded up the elders who are involved, they bundle them into a 504 Saloon car in which one of the elders was attempting to get away and set all of them ablaze. Ebiere takes responsibility for their deaths and she is arrested and sentenced to death by the government. In the bid to obtain her release, the youths led by Tamuno Alaibe (Enyinna Nwigwe) form themselves into the Niger Delta Peoples United Force, and go to America and kidnap the Managing Director (MD) of Western Oil Company along with other American citizens who are held hostage. Unfortunately, the members of this group led by Tamuno Alaibe, are once again deceived as they are falsely made to believe that their demand, which is the unconditional release of Ebiere and other members of United People's Force, in the custody of the Nigerian government has been granted. But the deceit is couched in the disguise and policy that American government does not negotiate with terrorists on American soil, without looking at the merit of the case.

With this piece of news that Ebiere has been unconditionally released, the United Peoples Force lay down their arms and freed the hostages in their custody. Their sense of betrayal and disappointment in the hands of the American government, their own government and the executives of the Western Oil Company, can best be imagined when the news filters in moments after laying down their arms that Ebiere has been killed by hanging. Forlorn and hopeless, they allow themselves to be arrested by the American police. As they are bundled into police vehicles, the movie comes to an end. The scenario just described above is tantamount to the betrayal and cause of the violence which characterizes Niger Delta and which has been described as "pure criminality of the highest order, arising from total disregard for constituted authority" (Chinweizu 2013) and leading to the attraction of "a great deal of attention over the years" (Amodu, O. Lanre and Idowu 2011).

While citing Chief Eddie Ugboma, a filmmaker who gave up filmmaking at the inception of Nollywood, according to (Okoye 2007) argues the critic should 
function to lift the industry through constructive, contributive advice." The film, Black November, as directed by Jeta Amata, though classified as drama, cannot be regarded as a conventional feature film. It falls closer to the genre of docudrama or faction because it uses a very large dose of historical materials. Examples are the scenes which feature the following: the pipeline fire explosion which took more than a thousand lives, reminiscent of the Jesse pipeline fire of 2012; the death of the elders who were set ablaze in their car, was a reflection of the Ogoni crisis of the 1990s which eventually led to the death by hanging of the writer, environmentalist and activist Kenule Saro-Wiwa and his colleagues by the Abacha junta. This is portrayed in the death by hanging via similar incidents of Ebiere Perema. Recall that the film opens in Warri prisons with the noose hanging threateningly in space and Ebiere lying in her lonely cell. There are other such instances even up to the dialogue as when the official of the Western Oil Company accused the villagers scooping the spilt oil of stealing and the statement that they deserved to die. The movie, can therefore, rightly be said to be another form of protest against oppression which is also a consequence of the sense of frustration borne out of the deprivation of their right to their God given natural resources. It is an attempt to enlighten the people about the evils of bad governance (Ojo and Ojakojo 2019). This further justifies the use of the theory adopted here.

Thematically, Amata's Black November can be compared to such historical epic films as Alexandre Dumas' 1844 novel, The Three Musketeers (Anderson et al. 2011) adapted into film with the same title, in 2011, and whose screenplay was written byAlex Litvak and Andrew Davies and directed by Paul W. Anderson; also as The Man in the Iron Mask (1998); directed by Randall Wallace who also wrote the screenplay; and (Heart 1995), directed by Mel Gibson; in its quest for justice. All the films have this thematic preoccupation for justice in common not withstanding their geographical, cultural and temporal disparities. The fact that the film is a protest against bad leadership has been substantiated from the foregoing examples. They also confirm the submission that "the leadership problem as experienced in Nigeria is a product of jettisoning the responsibility associated with it in preference to the privileges it carries", (Anyanwu 2017). Thematically, therefore, the film celebrates the failure of 
leadership at several levels and the consequences from such failure. First, there was leadership failure at the Federal and State government levels when they could not put in place policies that would safe-guard lives and property; there is equally leadership failure at the corporate level arising from the failure of the executives of Western Oil Company to be alive to their corporate social responsibility (CSR); and finally at the community level when the elders failed to provide the wisdom and guidance needed to tackle the challenges facing the community.

The environment, the entire community is a testimony of failure of all stakeholders. The community from which so much wealth is produced lacked the most basic of amenities- no drinkable water, no electricity, no road, indeed, nothing that shows that human beings live there. There is also failure at the level of the individual as many young people are idle and not gainfully employed; this is in a way a failure of government to provide employment. If the people were well taken care of, they would report oil spill rather than see it as a gift or bonanza from nature. Indeed, they would have been in their offices and the children would have been in their schools. Also, there is the theme of betrayal of trust, deceit, complicity, corruption, hypocrisy, etc. and the consequences which such aberrations can cause. Of course, one is not losing sight of the helplessness which forced the people to take laws into their hands in order to have control of their God given natural resources. In Black November, Amata used film as "a public agent with obligations to his society" (Onifade 2020), "to draw attention to some of such crises in the country that need immediate attention" (Ihentuge and S. 2018). (Ayakoroma 2017) sees Black November as "a film which portrays a community that is ravaged by crude oil exploration and exploitation activities of an oil multi-national in the volatile Niger Delta area." The film, however, can be criticized for one or two major weaknesses. First, it projects a victorvanquish approach to the Niger Delta conflict, contrary to the position of (Nykon 2011), who recommends three key strategies that producers of ficl ms must note towards achieving apeaceful society: (1) that there are viable alternatives to violentcontend-ing methods of conflict resolution; (2) that positive outcomes for both parties can often be created; and (3) that all parties are worthy of beingtreated humanely.

The plot of the movie shows that the story began in medias res, that is, at an advanced stage having started twenty-one years before Ebiere's birth but the 
pace peaked with her birth. We see her go through primary and secondary schools, winning scholarship from Western Oil to attend tertiary institution abroad. It seems her university education and her exposure to the whites while studying there made her the apt choice to be her family/community's spokesman, mediating between the people and the oil company. Moreover, the male members of her family were virtually wiped out in the pipeline fire explosion. Thus, the story is actually hers, told from her point of view. We first encounter her in her cell in Warri prisons and it is easy to know that the noose earlier seen dangling in the air is waiting for her as is the case at the end of the film. The irony of her death by hanging is not lost upon us as it reflects the relationship Nigeria and Nigerians have with multinationals and the international community. Had Ebiere remained abroad after her studies, not minding the fate of her people, she would have lived to a ripe old age, enjoying the privileges from her Western education which was a product of scholarship from the proceeds of her land. The scholarship was meant to be a sort of compensation on the one hand, and a bribe, on the other, to make her feel comfortable and neglect her people. When this did not work, she became a victim of her creators! This is may have informed (Brown 2018) position that "black consciousness in Western contexts is thoroughly embedded in, yet irreconcilable with, the ways that black consciousness is understood by the "other world that looks on in amused contempt and pity."

The language of the film alternates between the Queen's English of elite culture and the Nigerian English/pidgin, depending on the character. However, in some places, we are uncertain of the educational attainment of the character and this throws one off balance at the quality of the character's speech. For example, Ebiere's mother (Barbara Soky) speaks good English and considering her background, one is left to guess that she is probably educated. Irrespective of the character speaking, however, the language is simple, uncomplicated and easy to comprehend. Indeed, it helps to project the story both thematically and aesthetically.

Characterization in the movie is quite good as the casting directors did a very good job. Of course, there are few round characters as expected since the story cannot individualize every character. But such characters as Ebiere (Mbong Amata), Tamuno (Enyinna Nwigwe), Captain Hassan (Dede Mabiaku), Dede 
(Hakeem Kae-Kazim), Chief Kuku (Zack Amata), Gideon White (Fred Amata), the members of Niger Delta People's Force and some officials of the Western Oil Company, do stand out. In as much as most characterizations are in place, some characters and the actions associated with them make the story seem contrived. For example, at the scene of the pipeline explosion just as Ebiere is coming to see her mother and possibly pull her away from the spillage scene; it seems completely out of sequence that an oil company executive, who ought to know better, would be the one to light a match in such environment! It beats the imagination that he does not know enough to bridle his thirst for cigarette at that point in time.

Indeed, even the first gun shots designed to frighten the crowd are uncalled for in such environment. Similar to this is also the scene, where the five members of the people's force are killed by the government forces. Perhaps, the situation would have been controlled but for the small boy who allowed his balloon to explode, thus grating on the nerves of the two opposing forces, leading to the shootout. The point being made here is that those scenes and situations could have been handled better without making the sources of both tragedies obvious. The presence of the little children with the balloons as onlookers in such a tense environment makes light of the film. Moreover, the opposing forces have come from such distance to the venue of the tryst; the children's presence is therefore totally uncalled for. Notwithstanding this however, the casting of the central characters is good and characterization is equally effective especially as they brought their various experiences to bear, being seasoned show business men and women with lots of acting credits in their curriculum vitae.

The stunt team coordinated by Tom Proctor did a good job with the stunts especially with the pipeline explosion despite the careless method of making the character which started the fire to be so obvious in the manifestation of his ignorance. Also, the effect in the scene where the elders are burnt in the 504 salon car is good. The gunshots and deaths showed a remarkable departure from what used to obtain where guns are shot without any visible impact. Generally the effects are quite standard. The costume and makeup designer did a good job also. However, in one of the mourning scenes, some of the mourners are quite excited in their dancing to the point of almost contradicting the mood which ought to be sober. The location manager and scene designer measured up very well. The cell 
in the Warri prisons and most of the Niger Delta locations are quite appropriate and helped the aesthetic import of the film. The foreign scenes are also handled with expertise knowledge as the accidents at the kidnapping scene looked plausible in the manner and method of Hollywood. Overall, the film Black November, as directed by Jeta Amata, is an improvement on the Nigerian film industry, Nollywood. It is more so as the film is a vehement and courageous voice raised in protest against the evil being perpetrated in the Niger Delta by the federal government, corporate multinational industries and some well placed individuals in the society. Indeed, the film is one of the most authoritative evidences that showcase intolerance and political oppression of government against its people.

As experts have noted, oil theft in the Niger Delta is not a new development. What appears to be recent are the documentation and dimension of such theft. (Anikpo 2015) has noted that "one of the sad fact(s) about oil theft in Nigeria is not as recent as many people think. Unfortunately, written record(s) are scarce on the early history of this crime. Even more so is the fact that the earlier versions of oil theft involved highly technical operations for which information was available only to the perpetrators." The concerns of the Niger Delta region of Nigeria over issues of environmental degradation, pollution, deforestation and all kinds of political, economical, socio-cultural, human rights and other kinds of abuse, moral and spiritual are extremely worrisome because they are immediate and urgent. They are presently being intensified and worsened by the marauding and murdering hired assassins whom Nigerians prefer to call Fulani herdsmen for whatever reasons. Thus, Black November is perhaps one of the earliest audiovisual voices of protest raised against the evil being unleashed on the region as a consequence of its natural resources. Watching the film however can aggravate and should aggravate anger, frustration, helplessness and should provoke some action no matter how impotent. But, that is if one reads and sees it for what it really is: a docu-fiction or docu-drama. Otherwise, it can pass for any other movie where anything goes.

The few grey areas in the film come from some of the songs and call signs used. For example, the chorus, "Solidarity forever" is not quite appropriate despite the fact that it is a hackneyed presence in Nigerian unionism protests. Also, the 
answer response call of Theatre Arts students of a particular university in Nigeria, "Catch Me" "Throw away" and the reverse, is completely out of place in the movie. Barring this and some other minor, if negligible blemishes like having the Western Oil Company executive light a cigarette at the scene of the crude oil spill thereby igniting the fire that caused the explosion; and the children holding balloons at such a tense scene, the film is a true reflection of the Niger Delta situation in Nigeria today. The question that readily comes to mind is: What in the world are the boys doing in such a place in the first instance. Generally, however, Amata's Black November is a good and commendable voice of protest designed to address the injustice and inhumanity meted out to the people of Niger Delta region of Nigeria by the international and local powers that be. This substantiates the submission that film serves as a means "for the uplifting of humanity" (Anyanwu 2017).

\section{CONCLUSION}

Amata's Black November, effectively captures the inhuman treatment, injustice, environmental degradation and Nigerian government's insensitivity to the plight of the people which is at the nexus of the incessant militancy and protest that characterize the region. It is a well researched effort taken from historical events in the region that is presented in the film in the form of filmic 'faction." The thematic concerns raised in the film justify the use of the relative deprivation theory deployed in the paper. Indeed, Amata has been able to raise the salient concerns of the Niger Delta region of Nigeria to global attention through the thematic preoccupations in the film. This is also in line with the main objective of the paper which is to find out to what extent the filmmaker was able to address the issues of concern in the Niger Delta region of Nigeria. It is an eloquent testimony of an artist alive to the pulse of his society. 


\section{REFERENCES}

Amodu, O. Lanre and Idowu, Sobowale. 2011. "Intervening Factors in Conflicts between Oil Companies and Host Communities in Nigeria's Niger Delta." Journal of Communication and Media Research 3:93-104.

Anderson, Paul W. S., Logan Lerman, Matthew Macfadyen, Luke Evans, Milla Jovovich, Ray Stevenson, and Orlando Bloom. 2011. The Three Musketeers.

Anikpo, Mark. 2015. Oil Theft, Oil Bunkering and Environmental Degradation in the Niger Delta, in Oil Theft, Environmental Degradation and the Reciprocal Responsibilities of Host Communities and the Government in Nigeria: A Book of Readings. edited by C. Ewhrudjakpo.

Anyanwu, Chukwuma. 2008. "Bridging the Interface between Science and the Humanities through the Use of Film in Solving Human Problems." Journal of English Literature and Cultural Studies 1 (1):118-29.

Anyanwu, Chukwuma. 2017. "Theatre and Film as Catalyst to Leadership Change in Nigeria." Nigerian Theatre Journal 17 (2):35-45.

Apuke, O. D. 2017. "Exploring the Issues in Oil Production in the Niger Delta Region of Nigeria Security Challenges and Suggested Solutions." Arabian Jurnal of Business and Management Review.

Ayakoroma, Barclays F. 2017. "Contextualising Change in Nigeria's Leadership Question through the Film Medium: A Critical Reading of Jeta Amata's Black November." Nigerian Theatre Journal 17(2):1-17.

Bazunu, U. M. Harrie and Clement E. Ekong. 2017. "Chronicles of an Oil Suffused Environment in Niger Delta Visuals." Wilberforce Environment in Niger Delta Visuals." Wilberforce Island." A Journal of the Faculty of Arts, Niger Delta University, Wilberforce Island, Bayelsa State Nigeria $15: 25-45$.

Black November. 2012. Dir. and Prod. Jeta Amata; Feat.: Anne Heche, Akon, Vivica. A. Fox, Mbong Amata, Hakeem Kae-Kazim, Wyclef Jean, Sarah Wayn Callies, Kim Basinger, Mickey Rourke.

Brown, Matthew H. 2018. 'Osuofia Don Enter Discourse:' Global Nollywood and African Identity Politics.” IJOTA: Ibadan Journal of Theatre Arts 2-4: 5672.

Chiluwa, A. 2011. "Media Representation of Nigeria's Joint Military Task Force in the Niger Delta Crisis." International Journal of Humanities and Social Science 9 (1):197-207. 
Chinweizu. 2013. Caliphate Colonialism: The Taproot of the Trouble with Nigeria.

Darah, G. Godoni. 2014. The Niger Delta: Resource Control and the Quest for Justice. Ibadan: Kraft Books.

Dede, Sam A. and Emimeke Henry D. 2017. "The Reigns of Crude Oil, Politics, Poverty and Militancy in the Niger Delta Region." Journal of Humanities and Cultural Studies 299-114.

Ebekue, Onyekachukwu E. And Michael Chibudem Nwoye. 2019. "Nollywood Interventions In Niger Delta Oil Conflicts: A Tudy of Jeta Amata's Black November." A New Journal of African Studies 15(1):2.

Ebewo, Patrick. 2007. "The Emerging Video Film Industry in Nigeria: Challenges and Prospects." Journal of Film and Video 46-57.

Emasealu, Emmanuel. 2008. "A Study of the Theme of Ritual in Selected Nigerian Video Films." IJOTA: Ibadan Journal of Theatre Arts 2(4):94107.

Falola, Toyin. 2013. Literary Imaginations and Nation Building in Nigeria since 1914. edited by Ibadan. Diktaris.

Heart, Brave. 1995. Dir. Mel Gibson; Feat: Mel Gibson, Sophie Marceau, Angus Macfadyen, Catherine McCormack, Parick McGoohan and Brendan Gleeson; Duration: 3hrs 2mins.

Ibagere, Elo. 2011. "Human Capital Development in the Niger Delta: The Role of the Mass Media in the Process." Pp. 201-13 in The Humanities and Human Capital Development, Abraka Studies in African Arts II. Abraka: Ababa Press.

Idebe, Abel. 2019. "Promoting Minority Voices through Theatre for Development: The Erema TfD Experience." Alabar Journal of Liberal Studies: An Interdisciplinary Journal 21(1):177-83.

Ihentuge, Chisimdi U., and Kelechi Ogbonna S. 2018. "Nigeria and Conflict Resolution Issues in Africa: Nollywood's Critique in State of Emergency." New Frontiers: A Journal in the Humanities 2(1):49-66.

Iyang, Ofonime. E., and G. Morison Ime. 2018. "Strategies for Countering Terrorism and Mass Uprising in Nigeria: Readings from Select Nigerian Plays." Pp. 93-109 in Theatre, Counter Terrorism and the Nigerian Space: Proceedings of the 31st Annual Convention and International Conference of the Society of Nigeria Theatre Artists (SONTA). Oye-Ekit: Oye-Ekiti, Federal University. 
Jim, Oviasuyi P. O., and Uwadiae. 2010. "The Dilemma of Niger Delta Region as Oil Producing States of Nigeria." Journal of Peace, Conflict and Development Issue 115.

Kennedy, Courtney, Mark Blumenthal, Scott Clement, Joshua D. Clinton, Claire Durand, Charles Franklin, Kyley McGeeney, Lee Miringoff, Kristen Olson, and Douglas Rivers. 2018. "An Evaluation of the 2016 Election Polls in the United States." Public Opinion Quarterly 82(1):1-33.

Kolade, Seun. 2016. "Revisiting Jeta Amata's 'Black November." Retrieved April 13, 2020 (nantygreens.com/features/black-november-jeta-amata/).

Lawson, Jennifer, and King Bryn. 2012. "Theories of Violence: A Review of Textbooks on Human Behaviour and the Social Environment." Journal of Human Behaviour in the Social Environment 22(5):517-34.

Licata, Laurent, Simona Lastrego, Rosa Cabecinhas, and Sammyh Khan. 2017. "Social Representations of Colonialism in Africa and in Europe: Structure and Relevance for Contemporary Intergroup Relations." International Journal of Intercultural Relations 62:68-79.

Lucas, Joseph M., Fatima D. Vakkai, and Tordue Simon Targema. 2020. "Mirroring The Conflict Situation of The Oil-Rich Niger Delta Region of Nigeria On The Screen: A Thematic Analysis of The Film - Black November." Journal of Media Studies 2(2):125.

Nwankwo, B. O. 2015. "The Politics of Conflict over Oil in the Niger Delta Region of Nigeria: A Review of the Corporate Social Responsibility Strategies of the Oil Com-Panies." American Journal of Educational Research 3(4):383-92.

Nykon, B. P. 2011. "The Feature Film as a Vehicle for Disseminating Principles of Conflict Resolution." Journal of Conflictology 2(2):18-30.

Ojo, Cornelius A., and Oluwatosin O. Ojakojo. 2019. "Terrors and Horrors of Struggle in the Niger Delta: A Study of Hibbert's Blood and Oil and Amata's Black November." Nigerian Theatre Journal 19(2):30-44.

Oju, Enakeno V., and Chukwuma Anyanwu. 2018. "Feminist Approach as an Option in Contending Economic Recession: 'Husband for Hire' Telenovela as a Paradigm." International Review of Humanities Studies 3(2):404-23.

Okoye, Chukwuma. 2007. "Looking at Ourselves in Our Mirror: Agency, Counter-Discourse, and the Nigerian Video Film." Film International 5(4):20-29. 
Omoera, O. S. 2019. "Human Rights Issues in the Nigerian Films October 1 and Black November." Pp. 237-55 in African Cinema and Human Rights. Bloomington: Indiana University Press.

Omoera, Osakue S., and Chukwuma Anyanwu. 2020. "Politics of Succession in Nollywood Films." Saworoide and Ikoka. CINEJ Cinema Journal $8(1): 185-217$.

Onifade, Olufemi S. 2020. "Beyond the Lens: Kemi Adetiba's Kings of Boys as a Metaphor for Power and Order in Democratic Nigeria." The Journal of Society and Media 4(1):31-48.

Shaka, Femi. 2003. "Rethinking the Nigerian Video Film Industry: Technological Fascination and the Domestication Game." Pp. 41-50 in African Video Film Today, edited by F. Ogunleye. Manzini: Academic Publishers.

Shehu, B. 1995. "Cinema and Culture in Africa." Pp. 97-104 in Africa and the Centenary of Cinema. Ouagadougou: Presence Africaine.

Ukadike, Frank N. 1995. "African Films: A Retrospective and a Vision for the Future.” Pp. 47-68 in Africa and the Centenary of Cinema. Ouagadougou: Presence Africaine.

Wetkos, A., and R. Embu. 2019. "Gender Stereo-Typing in Isong's A Time to Love and Ezenwa's Executive Mess.” Pp. 366-82 in Fighting from the Trenches. Awka: Society of Nigeria Theatre Artists. 